\title{
Den digitale transformations betydning for ny viden
}

Louise Møller, Professionshøjskolen UCN

Karina Astrup Skjølstrup Larsen, Professionshøjskolen UCN

\begin{abstract}
Ligesom viden er et mangetydigt ord, kan vidensformer og hvad det vil sige at vide noget beskrives på forskellige måder. Uddannelses- og Forskningsministeriet beskriver gennem bekendtgørelsen for erhvervsakademiuddannelser og professionsbacheloruddannelser, hvilken slags viden, ministeriet mener, de studerende skal have tilegnet sig efter endt uddannelse - samlet for disse vidensformer er, at der skal være tale om ny viden. Det vi ikke ved, det er, om ny viden og måden ny viden indhentes på, påvirkes af den digitale transformation. Formålet med dette studie er derfor at undersøge, hvad studerende og undervisere ved professionshøjskolerne, forstår ved begrebet ny viden, samt hvordan og hvilke kanaler de anvender i deres søgen efter ny viden. Resultatet af studiet viser, at forståelsen for begrebet ny viden ikke er forskellig om man spørger studerende eller undervisere på to forskellige uddannelser ved Professionshøjskolen UCN, ligesom definitionen af begrebet ny viden ikke synes påvirket af den digitale transformation. Der ses heller ikke store forskelle mellem de studerende og underviserne i forhold til, hvor de søger og indhenter ny viden. Noget kunne dog tyde på, at søgevanerne hos de studerende og underviserne har ændret sig gennem de sidste 10 år - her sætter den digitale transformation måske sit præg.
\end{abstract}

\section{Engelsk abstract}

Knowledge can be understood in multiple ways and similarly, knowledge types and what it means to know something can be described in different ways. The Danish Ministry of Higher Education and Science in the Ministerial Order on Academy Profession and Professional Bachelor Study Programmes describes the type of knowledge which, according to the Ministry, students must have obtained at graduation. Overall, these types of knowledge must represent new knowledge. It is unknown if new knowledge and the way knowledge is obtained are affected by the digital transformation. The purpose of this study was to investigate how students and educators understand the concept of new knowledge as well as how and through which channels they search for new knowledge.

The results of the study showed that understanding of the concept of new knowledge was similar among both students and educators at two education programmes at the university college UCN in Denmark. Moreover, students and educators did not believe the definition of the concept of new knowledge was affected by the digital transformation. There were no major differences in the way students and educators searched for and gathered new knowledge. It seems, however, that search strategies among students and educators have changed during the past 10 years; this may be partly explained by the digital transformation. 


\section{Baggrund}

Viden er et mangetydigt ord. Mangetydigheden befinder sig på flere forskellige planer og vi benytter ordet i de mest forskelligartede betydninger. Med afsæt i Aristoteles er der tale om tre forskellige vidensformer; den teoretisk-videnskabelige viden (episteme), den praktisk-produktive kyndighed (techne) og den praktiske-etiske klogskab (fronesis) (Gustavsson, 2000). Andre igen, for eksempel Dietrich Benner, mener viden kan inddeles i seks vidensformer; livsverdensforståelse, den scientistiske vidensform, den historisk rekonstruerende vidensform, den ideologikritiske vidensform, den forudsætningskritiske vidensform og den anvendelsesorienterede vidensform (Engelhardt, 2007).

Ud over forskellige måder hvorpå vidensformer kan beskrives, så er der også forskellige opfattelser af, hvad det vil sige at vide noget og hvilken viden, der er bedst: videnskabelig viden, anvendt viden eller noget tredje som "principled practical knowledge" (Bereiter, 2014) eller "actionable knowledge" (Markauskaite \& Goodyear, 2017). Uddannelses- og Forskningsministeriet beskriver gennem bekendtgørelsen for erhvervsakademiuddannelser og professionsbacheloruddannelser, hvilken slags viden, ministeriet mener, de studerende skal have tilegnet sig efter endt uddannelse:

\section{"Uddannelsernes videngrundlag er erhvervs- og professionsbaseret samt udviklingsbaseret" (Uddannelses- og Forskningsministeriet, 2018).}

Erhvervs- og professionsbasering indebærer i denne sammenhæng, at uddannelsen er baseret på ny viden om centrale tendenser inden for det erhverv eller den profession, som uddannelsen retter sig mod. Udviklingsbasering indebærer, at uddannelsen er baseret på ny viden fra forsøgs- og udviklingsarbejde, som er relevant for det erhverv eller den profession, som uddannelsen retter sig mod. Udviklingsbasering indebærer desuden, at uddannelsen er baseret på ny viden fra forskningsfelter, der er relevante for de kerneområder, der er konstituerende for uddannelsens formål og erhvervssigte (Uddannelses- og Forskningsministeriet, 2018).

Vi støder i ovenstående på forskellige former for viden; ny viden om centrale tendenser, ny viden fra forsøgs- og udviklingsarbejde og ny viden fra forskningsfelter (Uddannelses- og Forskningsministeriet, 2018). Samlet for disse former for viden er, at der skal være tale om ny viden. Videre i bekendtgørelsen om uddannelsen til professionsbachelor som lærer i folkeskolen står der beskrevet som et færdighedsmål, at den studerende skal kunne udvikle læremidler til danskundervisning på grundlag af forskningsbaseret viden (Uddannelses- og Forskningsministeriet, 2015). I Bekendtgørelsen om uddannelsen til professionsbachelor i radiografi står der om de studerende, at de skal kunne mestre udvikling af egen fagidentitet på baggrund af evidensbaseret viden, kritisk refleksion og faglig vurdering i professionsudøvelsen (Uddannelses- og Forskningsministeriet, 2016). I førnævnte to uddannelser skal der altså indgå henholdsvis forskningsbaseret og evidensbaseret viden og når dette kobles med Uddannelses- og Forskningsministeriet forventning, må der være tale om ny forskningsbaseret og ny evidensbaseret viden indenfor de respektive felter.

Helt grundlæggende er der forskellige holdninger til, hvordan man kan komme til at vide noget - eller hvordan viden kan indhentes. En måde, hvorpå indhentning af viden kan beskrives er, at viden er noget vi indhenter i skrifter og databaser, den kan opfattes som en afgrænset størrelse, som en slags pakke, vi kan sende mellem mennesker og steder. Viden kan altså være fritstående i forhold til os selv, noget vi finder i medier, opslagsbøger eller lærebøger. Når vi siger, at vi indhenter viden, antyder det, at viden er noget, der er adskilt fra os, men som vi kan tilegne os (Gustavsson, 2000). Set fra dette perspektiv kan viden altså indhentes i forskellige typer af skrifter, databaser og medier.

I forhold til brugen af medier, herunder online medier, så ser det ud til, at vi bruger en stadig større del af vores vågne timer online. Den yngste halvdel af befolkningen er de flittigste brugere af internettet, og i 2018 går hhv. 95 pct. af de 16-24-årige, 89 pct. af de 25-34-årige og 91 pct. af de 35-44-årige på 
internettet flere gange om dagen (Statistics Denmark, 2018). Danmarks statistik undersøger hvert år befolkningens anvendelse af it. Heri fremgår det af tallene fra 2018, at hver fjerde dansker anvender sociale medier i forbindelse med deres beskæftigelse. Mere end hver anden dansker (70\%) anvender Facebook hver dag og der er 28\% af den danske befolkning, som har en profil på LinkedIn, og 10 \% på Twitter (Statistics Denmark, 2018). En analyse fra Mindshare, som er gennemført for Kulturstyrelsen fastslår videre, at $86 \%$ af danskerne har en profil på mindst ét socialt medie. Det kan være Facebook, Snapchat, Instagram, LinkedIn, Twitter, Google+ eller andet. Samtidig siger $11 \%$, at de sociale medier er det vigtigste nyhedsmedium for dem (Mindshare, 2016).

Ovenstående medieforbrug giver os anledning til at antage, at studerende og undervisere i højere grad end tidligere gør brug af digitale medier i deres søgen efter ny viden. Her spiller digital transformation måske ind. Den digitale transformation defineres på forskellige måder, men kan forstås som teknologiens indvirkning på processer, organisationer og individer (Redecker, 2017). I dette studie undersøges og diskuterer om udviklingen af digitale værktøjer og medier påvirker forståelsen af begrebet ny viden og de kanaler der gøres brug af til indhentning af ny viden. Resultaterne denne artikel kommer frem til kan anvendes til at belyse, om der er behov for justering af undervisningspraksis, så der er overensstemmelse mellem studerendes og underviseres forståelse og praksis.

Artiklen retter sig mod undervisere på professionshøjskolerne - men også undervisere på andre uddannelsesinstitutioner vil kunne drage nytte heraf. Den kan også med fordel læses af uddannelsesledere, mellemledere og topledere på videregående uddannelsesinstitutioner, da de har til opgave at sikre, at der er vilkår for underviserne til, at de besidder de nødvendige digitale kompetencer og rammer til at ændre didaktiske design, når dette findes nødvendigt. Sidst men ikke mindst kan pædagogiske it-konsulenter hente inspiration i denne artikel ift. sparring med og tilrettelæggelse af kompetenceudvikling for undervisere.

\section{Formål}

Flere har tidligere forsket i hvilken betydning teknologiens udvikling har på uddannelse. Nina Bonderup Dohn har blandt andet lavet studiet "Web 2.0: Inherent tensions and evident challenges for education"(Dohn, Hansen, \& Hansen, 2019). Francesco Caviglia med flere har undersøgt hvad universitetsstuderendes digitale læringsmiljøer består af (Caviglia, Dalsgaard, Davidsen, \& Ryberg, 2018), mens Maria Hvid Stenalt og Mikkel Godsk har undersøgt "Studerende og underviseres brug af digitale medier - En kvantitativ undersøgelse af Aarhus Universitets studerende og underviseres brug af digitale medier og internettet anno 2008" (Stenalt \& Godsk, 2009). Der findes imidlertid ingen forskning, der belyser, om den digitale transformation har ændret forståelsesrammen for begrebet ny viden med perspektiver fra studerende og undervisere ved professionshøjskolelerne.

Formålet med dette studie er derfor at undersøge, hvad studerende og undervisere ved to af UCNs uddannelser, Lærer- og Radiografuddannelsen, forstår ved begrebet ny viden indenfor deres fag og hvilke kanaler de anvender i sin søgen efter ny viden.

\section{Metode}

Der er valgt en kvalitativ forskningsmetode til dataindsamling i studiet; spørgeskema indeholdende åbne spørgsmål. Denne metode er velegnet, når forskningsmålet er at få viden om og forståelse for menneskers livsverden; fx en praksis om ny viden (Vallgårda \& Koch, 2011). Da der er mange uddannelser knyttet til UCN, vælges to uddannelser ud; Radiografuddannelsen og Læreruddannelsen. Med udgangspunkt i disse to uddannelser er studiet derfor en kvalitativ undersøgelse af studerendes og underviseres forståelse af begrebet ny viden og hvor der søges efter ny viden. Studierne er udført internt på UCN i perioden fra marts 2019 til maj 2019. 


\section{Spørgeskema}

Spørgeskemaerne som sendes ud til de studerende og underviserne er ikke helt ens. Forskellighederne i spørgeskemaerne ses ved at underviserne spørges ind til anciennitet, uddannelse og titel, og de studerende til tidligere uddannelse, samt semester på nuværende uddannelse ved UCN. Spørgsmålene omhandlende ny viden og indhentning af denne er ens og er fremkommet via viden fra kilderne der er anvendt i denne artikel, deres referencer samt erfaringer fra vores virke som lektorer har også bidraget som baggrund for spørgerammen.

Tabel 1. Spørgsmålene omhandlende ny viden.

\begin{tabular}{|l|}
\hline Spørgsmål omhandlende ny viden \\
\hline Beskriv hvordan du i uddannelses sammenhæng forstår begrebet "ny viden"? \\
\hline Hvor søger du efter ny viden? (nævn gerne flere) \\
\hline Hvad anser du som værende valide kilder? \\
\hline $\begin{array}{l}\text { Hvilke digitale Apps, værktøjer eller søgemaskiner anvender du i forbindelse med dit studie, i } \\
\text { forbindelse med at søge ny viden? (Nævn gerne alle du anvender) }\end{array}$ \\
\hline Hvad er din vurdering af viden hentet på de digitale medier - herunder LinkIn, Twitter osv.? \\
\hline Hvad er din vurdering af viden hentet fra analoge kilder - herunder artikler, fagbøger osv.? \\
\hline
\end{tabular}

Der udsendes pilotspørgeskema til enkelte personer for at teste forståelse af spørgsmålene. Link til spørgeskemaet udsendes via mail til både undervisere og studerende og der gives en frist på 14 dage til besvarelse og derefter sendes en reminder. Samlet er der åbent for svar på spørgeskema i 3 uger.

\section{Etisk godkendelse}

Før studierne starter, undersøges det hos videnskabsetisk komité, om godkendelse derfra er nødvendigt, hvilket ikke er tilfældet. Studiet er derfor baseret på frivillig deltagelse fra studerende og undervisere, da de frit kan vælge ikke at besvare spørgeskemaet.

Deltagernes anonymitet forsøges sikret ved, at besvarelserne er anonyme, da ingen personlige oplysninger som navne eller bruger-id gemmes ved besvarelse af spørgeskemaet. Data fra spørgeskemaerne opbevares derudover anonymiseret på en computer med login.

\section{Dataanalyse}

Data bliver analyseret ud fra en fænomenologisk baseret meningskondensering inspireret af Giorgi (Giorgi, 1975) beskrevet af Kvale (Kvale \& Brinkmann, 2014). Meningskondenseringen har derfor følgende faser:

1. Data fra spørgeskemaerne bliver læst igennem, så helheden fornemmes.

2. Forskerne identificerede informanternes forståelse af fænomenet ny viden, og hvor der søges efter ny viden, som de bliver udtrykt af informanterne.

3. Forskerne samler informanternes forståelser og beskriver en samlet meningen heaf.

4. Temaerne, der dominerer identificerede forståelser, bliver formuleret, så enkelt som muligt. (Da der for nogle temaer er tale om meget faktuelle svar, vil der være mere tale om en liste frem for kondensering). 


\begin{tabular}{|l|l|l|}
\hline Svar & Meningskondensering & Kategorisering \\
\hline - Peer-reviewed artikler, internationale & Underviserne anser flere & Kilder der anses som \\
journals på BFI-listen. Klassisk, oprindelig & kilder som værende & valide. \\
litteratur og wikipedia. & valide, herunder nævner & \\
- Studier baseret på velbeskrevet valid & de peer-reviewed artikler, & \\
metode og veldokumenteret & journals på BFI-listen, & \\
dataindsamling. & andre tidsskrifter, & \\
- Bøger, tidsskrifter og tidsskriftdatabaser. & tidsskriftsdatabaser, & \\
- Rapporter fx fra Danmarks & studier baseret på & \\
Evalueringsinstitut. & velbeskrevet valid metode & \\
- Netværk, forlag, mails, tidsskrifter og & og veldokumenteret & \\
kolleger. & dataindsamling, forskning & \\
- Forskning fra universiteter. & fra universitetet, Ph.d.er, & \\
- Artikler i seriøse faglige/tidsskrifter, & rapporter, netværk, & \\
forskningsprojekter, ph.d.-oplæg, materiale & forlag, mails og kolleger. & \\
skrevet til studerende som henviser til & & \\
bagvedlæggende forskning. & & \\
\hline
\end{tabular}

\section{Resultater}

Spørgeskemaerne er udsendt via Microsoft Forms til alle undervisere og studerende på Læreruddannelsen (145 undervisere/1415 studerende) og Radiografuddannelsen (9 undervisere/144 studerende) ved UCN.

Svarprocenten udregnes ud fra følgende formel:

$($ Antal besvarelser $/$ Antal adspurgte $) * 100=$ svarprocent

Tabel 3. Antal svar og svarprocent.

\begin{tabular}{|l|l|l|}
\hline & Lareuddannelsen & Radiografuddannelsen \\
\hline Undervisere & 16 stk. / 11\% & 4 stk. / 44,4\% \\
\hline Studerende & 58 stk. / 4,1\% & 54 stk. / 37,5\% \\
\hline
\end{tabular}

Resultaterne præsenteres i forhold til de af analysen fremkomne temaer; definition på begrebet ny viden, her kan ny viden findes, kilder der anses som valide, vurdering af kilder hentet fra digitale medier og vurdering af viden hentet fra analoge kilder.

\section{Definition på begrebet ny viden}

Om begrebet ny viden beskriver de studerende, at det er viden, som de ikke kendte før eller som ny viden de tilegner sig. Ny viden beskrives af de studerende som værende et bredt spektrum mellem teori og praksis. En studerende skriver: Vi bliver introduceret for ny viden både gennem praksis, teorier, forskning, undervisning og eksamen. De studerende beskriver videre, at der er tale om en refleksiv proces. De studerende skriver også om udvidelse af noget viden, man i forvejen har. En studerende skriver herom: At der kan drages nye konklusioner/sammenhænge baseret på viden man ikke har mødt eller havde før. Herudover beskriver de studerende, at ny viden skal være med til at udvide egen forståelse af sig selv og omverdenen - både teoretisk og praktisk. Et par studerende er inde på, at kilderne skal være udgivet indenfor de sidste 5-10 år. 
Underviserne skriver om begrebet ny viden, at det er viden, som ikke i forvejen er kendt. Videre beskriver underviserne, at ny viden kan have flere former. En underviser skriver: Jeg skelner mellem indre og ydre ny viden. Indre viden er nye erkendelsesprocesser i hjernen. Ydre viden er fx ny forskning på et område. En anden underviser supplerer: Der er tale om nye perspektiver på gamle problemstillinger. En enkelt underviser beskriver, at kilden ikke må være mere end ti år gammel.

\section{Her kan ny viden findes}

De studerende beskriver flere steder, hvor ny viden kan findes. Herunder nævner de: artikeldatabaser, ucnbib, flere søgefunktioner under google, forskellige faglige internetsider, tidsskrifter, faglitteratur, fagblade, nyhedsmedier, foredrag, podcast, wikipedia, sociale medier, radiopedia, youtube og videnskabelige film. De studerende beskriver videre, at ny viden hentes via undervisning/underviser, medstuderende, praksis, kolleger, venner, øvelser og studiejobs.

Underviserne beskriver ligeledes flere steder, hvor der kan findes ny viden. Herunder nævner de følgende steder: artikeldatabaser, forskellige søgefunktioner under google, forskellige faglige internetsider, ucnbib, statsbiblioteket, youtube, sociale medier, konferencer, poster, kurser, netværk, nyhederne, bøger, tidsskrifter, podcasts og TED-Talks.

\section{Kilder der anses som valide}

De studerende anser flere kilder som værende valide. Herunder nævner de: fagbøger, videnskabelige artikler, konferencer, undervisere, aviser, magasiner, nyhedskilder, artikeldatabaser, tidsskrifter, forskellige internetsider og Ph.d'er. De studerende lægger i deres vurdering af kilderne vægt på forskellige elementer. En studerende beskriver: Kilderne skal kunne redegøre for, hvor de har deres informationer fra. En anden studerende lægger vægt på: Forfatterens navn, årstal for udgivelsen og referencer til sekundære kilder. En anden studerende igen supplerer med: Kilderne må ikke have interessekonflikter inkluderet. Ud over førnævnte om valide kilder beskriver de studerende, at kilderne ikke bygger på subjektive holdninger, at der er tale om førstehåndskilder og/eller forfatterne bag kilden er knyttet til et validt institut. Hvis der er tale om artikler, beskriver de studerende, at disse gerne må være peer-reviewed samt have en høj validitet, reliabilitet og p-værdi (kvalitative studier).

Underviserne anser også flere kilder som værende valide, herunder nævner de peer-reviewed artikler, journals på BFI-listen, tidsskrifter, tidsskriftsdatabaser, forskning fra universitetet, Ph.d.er, rapporter, netværk, forlag, mails og kolleger. En underviser beskriver overordnet om valide kilder: Kilder der inkluderer studier, der er baseret på velbeskrevet valid metode og veldokumenteret dataindsamling.

\section{Vurdering af kilder hentet fra digitale medier}

I forhold til vurdering af viden hentet på de digitale medier er de studerende splittede. Nogle studerende beskriver, at der her ikke er tale om valide kilder. Disse studerende beskriver, at digitale kilder kan anvendes til inspiration, men da der ofte er tale om subjektive holdninger eller politisk propaganda ser de studerende, at der hellere skal søges efter alternative kilder. Andre studerende beskriver, at digitale medier kan være lige så valide som andre kilder, såfremt forfatteren fremgår og der linkes til referencer. En studerende beskriver herom: Der skal anvendes en tilstrækkelig mængde kildekritik. Viden fra de digitale medier kan være baseret på forskning, som kan være valid nok, beskriver de studerende. De studerende beskriver endvidere en fordel ved digitale medier i forhold til kilder i papirform og det er, at de er hurtigere at søge på. 
I forhold til vurdering af viden hentet på de digitale medier er underviserne også lidt splittede. På den ene side beskriver nogle undervisere om LinkedIn og Twitter, at de ikke indeholder viden, men de linker til informationer, som kan være valide. Modsat beskriver andre undervisere, at der kan være tale om meget interessant og nyttig viden, og der er mange gode portaler imellem. Underviserne er dog enige om, at det kræver solid faglig ballast at hente viden her og det $\mathrm{i}$ bund og grund handler om sammenhæng mellem indholdet, baggrunden og metoden, den aktuelle viden er fremskaffet på. Underviserne er kritiske i forhold til de medier, hvor alle kan skrive indhold ind.

\section{Vurdering af viden hentet fra analoge kilder}

Om viden hentet via analoge kilder beskriver de studerende, at det er valide/troværdige kilder, og der ofte kan findes en bredere viden i disse kilder. Men de studerende beskriver også, at man altid skal være skeptisk og vurderingen afhænger af, hvem der har skrevet kilden, hvornår den er skrevet og relevansen for emnet. De studerende beskriver nogle udfordringer, der kan forekomme ved brugen af analoge kilder. Her beskriver de blandt andet, at de hurtigere kan blive forældede, da de ikke opdateres som digitale kilder og de kan være sværere at søge i, hvis kilden ikke indeholder stikordsregister eller hvis kilden ikke er systematisk opbygget. Nogle studerende beskriver, at de analoge kilder mest anvendes som opslagsværker og som inspiration.

Om viden hentet fra analoge kilder beskriver underviserne, at der er tale om grundlæggende viden som er trygt og godkendt materiale. Underviserne beskriver, at der er tale om mere uddybet stof. Herom siger en underviser: De har bedre mulighed for fordybet diskussion. Generelt beskriver underviserne viden fra analoge kilder som værende valid med transparens og referencer samt lødig og troværdig viden. Enkelte undervisere beskriver opmærksomhedspunkter ved analoge kilder, her nævner de, at man også her skal tjekke kilder, forlag og forfatter. Andre undervisere beskriver, at der i analoge kilder oftere er tale om generel og ældre viden, som kan være forældet, da disse kilder er svære at opdatere.

\section{Diskussion}

De studerende og underviserne på de to uddannelser er enig om, at begrebet ny viden dækker over viden, som ikke i forvejen er kendt. Videre er de studerende og underviserne også enige om, at der kan være tale om udvidelse af noget viden eller erkendelser, man i forvejen har.

De studerende og underviserne beskriver flere steder, hvor ny viden kan findes, hvor flere af stederne går igen hos begge grupper: artikeldatabaser, forskellige søgefunktioner under google, forskellige faglige internetsider, ucnbib, fagbøger, tidsskrifter, nyhedsmedier, sociale medier, Youtube, podcasts og netværk. Her ses det, at studerende og undervisere i høj grad gør brug af digitale medier. I et studie om studerendes brug af digitale medier ved blandt andet videregående uddannelser i UK ses det ligeledes, at studerende i høj grad anvender digitale medier i forbindelse med deres studier (Newman, Beetham, \& Knight, n.d.). Samme tendens til brug af digitale medier i undervisning ses blandt undervisere ved blandt andet videregående uddannelser i UK og underviserne i rapporten Digital experience insights survey 2018 finder Twitter og Youtube særlig anvendelige (Newman et al., n.d.). Samtidig viser tal fra Statistikbanken.dk om udlån af analoge kilder på biblioteket på UCN, at der i 2018 er udlånt ca. 75.00o analoge kilder (Danmarks Statistik, 2019). Når dette udlån af analoge kilder ses sammen med, at der på Lærer- og Radiografuddannelsernes fag på Canvas også findes henvisninger til analoge kilder, så anvendes disse kilder også. Både de studerende og underviserne beskriver en udfordring ved brugen af analoge kilder, at de hurtigere end digitale medier kan blive forældede. Om denne problemstilling skriver Niels Jakob Pasgaard og Lise Marie Stein-Müller fra Det Nationale Videncenter for e-læring, at web-teknologierne har betydet, at viden ikke længere kan betragtes som statisk, men i stedet må betragtes som dynamisk og dermed også foreløbig (Pasgaard, 2010). 
Under digitale medier nævner både de studerende og underviserne anvendelse af sociale medier. Rune T, Steenberg, Digital project manager i virksomheden Brüel \& Kjær, er enig i, at man ikke kan se bort fra de sociale medier, når vi taler om viden og hvordan vi finder den (Mønsted, 2014). Under brugen af sociale medier nævner underviserne blandt andet Twitter. Om viden på Twitter beskriver Aarhus Universitet, at man på Twitter kan finde fagfæller at kommunikere med inden for sit fagområde. I Danmark er det nemlig primært videns-eliten, journalister og kendisser, der bruger Twitter. Flere uddannelsesinstitutioner er også begyndt at henvise deres forskere til at dele deres forskning via Twitter (Århus universitet, 2019). De studerende nævner Facebook som kilde til ny viden. Bibliotekar Sigrid Klitgaard Brix udtaler om facebook; "Lige så nemt det er at oprette en side på Facebook, lige så svært er det at udnytte potentialet og få noget brugbart indhold ud" (Mønsted, 2014). De studerende og underviserne er da også enige om, at hvad angår brugen af digitale medier til at hente ny viden, så skal forfatterne kunne redegøre for, hvor de har deres informationer fra, ligesom der ikke må være interessekonflikter tilstede. Underviserne beskriver videre, at der kræves en vis portion solid faglig ballast, for at kunne sortere den relevante viden fra alt den ikke brugbare viden.

I forhold til brugen af analoge kilder som fagbøger og forlag til at hente ny viden gennem, beskriver både de studerende og underviserne, at der er tale om kilder hvor grundlæggende og troværdig viden findes, men grupperne beskriver også, at der kan være tale om forældet viden. Noget kunne også tyde på, at brugen af analoge kilder er faldende. Tal fra Statistikbanken.dk viser nemlig om udlån af analoge kilder på UCN's bibliotek i perioden fra 2009 til 2018, at antallet er faldet fra ca. 88.800 udlån i 2009 til ca. 75.00o i 2018. Bestanden af analoge kilder i samme periode på samme bibliotek er ligeledes faldet fra ca. 193.00 analoge kilder til ca. 154.000 analoge kilder. Tendens til at ny viden ikke i samme omfang som tidligere hentes i analoge kilder understøttes af antallet at full-text downloads i samme periode fra 2009 til 2018. Her ses nemlig en markant stigning i perioden fra ca. 7600 til downloads til ca. 126.500 downloads (Danmarks Statistik, 2019).

\section{Begrænsninger}

Dette studie har nogle begrænsninger. I forhold til metoden for indsamling af empiri mener vi, at vi kun er kommet frem til tendenser, da der ved professionshøjskolerne er mange og forskelligartede uddannelser og der i dette studie kun er inkluderet et meget smalt udvalg. Gældende for de undersøgte uddannelser i denne artikel er sammenspillet med praksis også en vigtig faktor, da en del af undervisningsforpligtelsen ligger hos dem og deres forståelse af begrebet ny viden og anvendte kanaler til søgen herefter er ikke inkluderet. Der er behov for yderligere forskning for at få større kendskab til, om den digitale transformation har betydning for ny viden bredt set ved professionshøjskolerne.

\section{Konklusion og relevans for uddannelserne og}

\section{praksis}

Konklusionen på dette studie må være, at forståelsen for begrebet ny viden ikke er forskellig, om man spørger studerende eller undervisere på de to uddannelser; ny viden er viden, som ikke i forvejen er kendt. Derudover synes definitionen på begrebet ny viden ikke påvirket af den digitale transformation. Der ses heller ikke store forskelle mellem de studerende og underviserne i forhold til, hvor de søger og indhenter ny viden og flere kilder beskrives. Noget kunne dog tyde på, at søgevanerne hos de studerende og underviserne har ændret sig gennem de sidste 10 år - her sætter den digitale transformation sit præg. I forhold til denne udvikling har viden fået et nyt opsving - med IT-fortegn. Grunden hertil kan være, at mængden af information eller viden gør det umuligt at udskille den delmængde, som skulle kunne nedskrives i en læreplan eller lærebog og formidles. I stedet bliver det stadig vigtigere at lære at søge 
efter viden. Man må gå til registrene eller til databaserne for at søge. Tilsvarende sat på spidsen kunne man kalde en sådan opfattelse af viden for "viden som registre" (Gustavsson, 2000).

Uddannelses- og Forskningsministeriet er opmærksomme på betydningen af den digitale transformation, når de i et call for action skriver; "De videregående uddannelser spiller en central rolle, når det kommer til at klæde en ny generation på til fremtidens arbejdsmarked og til et samfund med nye digitale muligheder og udfordringer" (Uddannelse- og Forskningsministeriet, 2018). At de videregående uddannelser spiller en central rolle, stiller krav til undervisernes kompetencer på det digitale område. "European Framework for the Digital Competence of Educators" påpeger at underviseren skal besidde 22 elementære kompetencer som kan inddeles i 6 hovedområder (Professional engament, digital resources, teaching and learning, assessment, empowering learners og facilitating learners digital competence). I og med at blandt andet de sociale medier er blevet en brik i vidensproduktionen og vidensformidlingen, er det nødvendigt at tænke de nye teknologier/medier ind i pædagogikken (Pasgaard, 2010). I forhold til til dette studie, der viser overensstemmelse mellem de kanaler de studerende og undervisnerne gør brug af i deres søgen efter ny vide, ser det ud til på nuværende tidspunkt, at underviserne besidder de digitale kompetencer, der gør det muligt i deres didaktiske design at tage hensyn til eller udvikle de studerendes kompetencer til at indhente ny viden, være informationskompetente og kildekritiske.

\section{Referenceliste}

Århus universitet. (2019). Twitter-guidelines til forskere. Retrieved September 25, 2019, from https://medarbejdere.au.dk/fileadmin/www.medarbejdere.au.dk/Kommunikation/Twitter_guidelines_til_fo rskere_180515.pdf

Bereiter, C. (2014). Principled Practical Knowledge: Not a Bridge but a Ladder. Journal of the Learning Sciences, 23(1), 4-17. https://doi.org/10.1080/10508406.2013.812533

Caviglia, F., Dalsgaard, C., Davidsen, J., \& Ryberg, T. (2018). Studerendes digitale læringsmiljøer: læringsplatform eller medieøkologi? Tidsskriftet Læring Og Medier (LOM), 1O(18).

https://doi.org/10.7146/lom.v10i18.96928

Danmarks Statistik. (2019). Statistikbanken. Retrieved from https://www.statistikbanken.dk/statbank5a/default.asp?w=1500

Dohn, N. B., Hansen, S. B., \& Hansen, J. J. (2019). Designing for situated knowledge transformation.

Engelhardt, R. (2007). Vidensformernes kamp. Retrieved from http://www.epages.dk/aarhusuniversitet/202/html5/

Gustavsson, B. (2000). Vidensfilosofi. Aarhus: Klim. Retrieved from https://www.bogide.dk/produkt/237254/bernt-gustavsson-vidensfilosofi

Kvale, S., \& Brinkmann, S. (2014). Interview : det kvalitative forskningsinterview som håndværk. København: Hans Reitzels Forlag. Retrieved from https://www.saxo.com/dk/interview_steinar-

kvale_haeftet_9788741263779?dfw_tracker=1309828292072\&gclid=CjoKCQjwoKzsBRC5ARIsAITcwXEjL7nuyuz_ofMNNCOLvVaLtNbj-HgO9AIFwNXGwNOntfIRV36DlUaAp9IEALw_wcB

Markauskaite, L., \& Goodyear, P. (2017). Epistemic fluency and professional education: Innovation, knowledgeable action and actionable knowledge. Professional and Practice-based Learning (Vol. 14). https://doi.org/10.1007/978-94-007-4369-4_1

Mindshare. (2016). Gør sociale medier danskerne dummere? - Blogmindshare.

Mønsted, S. (2014). Lær at bruge den viden, de sociale medier gemmer.

Newman, T., Beetham, H., \& Knight, S. (n.d.). Digital experience insights survey 2018: findings from students in UK further and higher education. Retrieved October 22, 2019, from https://digitalinsights.jisc.ac.uk/news/digital-experience-insights-survey-2018-findings-students-uk-furtherand-higher-education/

Pasgaard, N. J. et. a. (2010). View of Vidensbegreber og nye interaktive medier. Retrieved February 6, 2020, from https://rauli.cbs.dk/index.php/revy/article/view/2985/3073

Redecker, C. (2017). European Framework for the Digital Competence of Educators: DigCompEdu. https://doi.org/10.2760/159770 
Statistics Denmark. (2018). Publikation: It-anvendelse i befolkningen 2018 - Danmarks Statistik. Retrieved October 23, 2019, from https://www.dst.dk/da/Statistik/Publikationer/VisPub?cid=29448

Stenalt, M. H., \& Godsk, M. (2009). Visning af: Studerende og underviseres brug af digitale medier - En kvantitativ undersøgelse af Aarhus Universitets studerende og underviseres brug af digitale medier og internettet anno 2008. Læring Og Medier, 2. Retrieved from https://tidsskrift.dk/lom/article/view/3910/3419

Uddannelse- og Forskningsministeriet. (2018). Teknologisk upgrade på de videregående uddannelser Uddannelses- og Forskningsministeriet. Retrieved October 22, 2019, from https://ufm.dk/uddannelse/videregaende-uddannelse/puljer/teknologisk-upgrade

Uddannelses- og Forskningsministeriet. (2015). Bekendtgørelse om uddannelsen til professionsbachelor som lærer i folkeskolen - retsinformation.dk. Retrieved September 25, 2019, from https://www.retsinformation.dk/Forms/Ro710.aspx?id=174218

Uddannelses- og Forskningsministeriet. (2016). Bekendtgørelse om uddannelsen til professionsbachelor i radiografi - retsinformation.dk. Retrieved September 25, 2019, from https://www.retsinformation.dk/Forms/Ro710.aspx?id=180540

Uddannelses- og Forskningsministeriet. (2018). LEP-bekendtgørelsen - Bekendtgørelse om erhvervsakademiuddannelser og professionsbacheloruddannelser - retsinformation.dk.

Vallgårda, S., \& Koch, L. (2011). Forskningsmetoder i folkesundhedsvidenskab (4th ed.). Kbh.: Munksgaard Danmark.

\section{Forfattere}

\section{Louise Møller}

Radiograf, Lektor

Professionshøjskolen UCN

\section{Karina Astrup Skjølstrup Larsen}

Pædagogisk IT-konsulent

Professionshøjskolen UCN

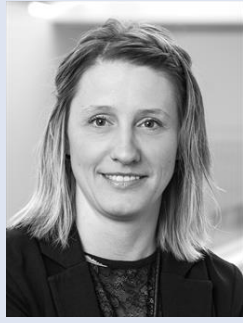

